\title{
Odyssey 'Round the World' and Homer in Croatia
}

Neven Jovanović, University of Zagreb

\section{* * Introduction}

Dear colleagues, I will be talking today about a microcosmos and a macrocosmos. Since we have gathered here to discuss images of antiquity in modern society, I will present to you, first, a very small image - which has the tendence to get smaller and smaller and, then, an unexpectedly large image which is strange, and only gets stranger. The first, the small image, tells the story of Homer in croatian translation. The second is the story of an international rhapsody (rhapsody in the Homeric sense of "stitching together") realised in December 2020 with the help of communications technologies and formats that we use every day: webcams, smartphones, YouTube videos. In a final reflection I will ask myself, and all of you, what could it all mean: where is antiquity (represented by Homer) on this microcosmos and macrocosmos spectrum, and where do we want it to go.

\section{** 1 Homer in Croatian: one translator, one meter; authority, strict rules, no readers}

In the first 18 years of this century, from 2001, there have been 14 new English translations of the Iliad, and 13 of the Odyssey. It seems that, in the case of Homer, new translations - mind you: brand new translations, not counting the reprints of already existing works - in English appear every six months. 
In Croatia, the situation is different. Currently there is exactly one translation of the Iliad and one of the Odyssey into croatian. Both were done by the same translator, Tomo Maretić (1854-1938). The translations were first published in Zagreb at the time when Croatia was still part of the Habsburg Empire, the Odyssey in 1882 and the Iliad in 1883. During the next 140 years, and over several national configurations, Maretić's translations have been republished again and again. Although until 1960 they have been revised constantly and significantly, the only versions of Homer we have in Croatian in the year 2021 are essentialy still the same our great-great-great-grandfathers (and mothers) have been reading in 1883, five generations ago.

Alright. But how did Maretić translate Homer, what did he see in the Iliad and the Odyssey? Maretić was not a poet. He was a philologist and a linguist, interested in standardizing croatian language - with all the ideological baggage that issue carried at the end of the 19th century. Maretić's main interests in Homer were two: finding an equivalent for the Homeric verse, and finding an equivalent for the Homeric language. The first interest led Maretić to define a set of rules for composing a "Croatian hexameter". In doing so, Maretić was inspired by Johann Heinrich Voß (Odysee 1781, Ilias and Odysee 1793) and Nikolaj Ivanovič Gnjedič (the Iliad, 1829) and Vasilij Andrejevič Žukovskij (the Odyssey, 1849) - the translators who turned Homer into German and Russian "in the metre of the original", developing in the process a verse that previously did not exist in their cultures.

Such verse did not exist because, as you will know, it is impossible to reproduce Greek hexameter into either German, Russian, croatian, Italian or Slovene "in the metre of the original". Homeric hexameter is a quantitative metre, and versification of our languages is based either on the accent, on the number of syllables, or on a combination of both. "In the metre of the original" actually means that the translators intended to recreate in their target languages the rhythmic and 
rhetorical effect of Greek hexameter verse - whatever they considered these effects to be.

I have mentioned the rhetorical effect. This brings us to the other of Maretić's interests in Homer. In his translation, Maretić used croatian colored with literary archaisms and with folksy and dialectal idioms. That was Maretić's equivalent of Homeric "artificially traditional" epic expression. It also relied strongly on supposed analogies between Homeric poetry and Southslavic epic.

Maretić's achievement impressed the critics and the professors. The canonical status of Maretić's Homer was further ensured by the quantity of Maretić's other translations from the classics Maretić translated not only Homer, but complete Vergil and Ovid's Metamorphoses as well. I would add, that a further important factor was Maretić's authority regarding the linguistic norm; Maretić was also the author of a Grammar and Stylistic of the Croatian or Serbian Literary Language (1899, 1931), of a Croatian or Serbian Linguistic Advisor, and one of the editors (1907-1938) of the Dictionary of the Croatian or Serbian Language published by the Yugoslav Academy of Sciences and Arts.

There were, however, two attempts to criticize Maretić's translation, both by poets. Vladimir Nazor in 1932 defended a freer form of croatian hexameter, which Nazor used for his own poems, and Antun Šoljan in 1978 described Maretić's Homer as "academic", somebody "writing other poetry, and not the Homeric one", "too rural" and "not Mediterranean enough".

But Šoljan's implicit challenge was not accepted. There is still no other Homer in Croatian but the one constructed by Tomo Maretić. (Yes, in 1996 there appeared one other partial translation. It was a singular, and, if I may say so, an almost Heideggerian, extremely literal and etymological, highly idiosyncratic and, consequently, impossible to understand 
translation of Book I of the Iliad, published in three versions by Bulcsú László). ${ }^{1}$ There were no attempts to present Homer in Croatian prose, in free verse, in some of traditional croatian verse forms; no attempts of poets to render Homer, either working alone or collaborating with philologists; there were no attempts to retell or paraphrase the stories. And yet, it is still expected of every croatian high school student to read at least a selection from the Iliad and the Odyssey. Personally, some forty years ago, when I was a highschool student and had to read Maretić's Homer, I strongly disliked the language. I think I was annoyed and disappointed by the same "folksy Homer" that bothered Šoljan. But to high school students today, Maretić's Homer very hard to understand - not yet quite as incomprehensible as the original Greek (to somebody who cannot read it), but getting there.

\section{** Odyssey 'round the world}

While thus the printed and reprinted Croatian Homer, monolithic and petrified, is sinking into incomprehensibility, in December of the last year, an international collaborative effort - connected with schools and universities, but completely voluntary and informal - used precisely the incomprehensibility of Homer as its main attraction. On that occasion, however, incomprehensibility was joined with mutability and variety; that Homer was far, far from a petrified and singular object.

The project Odyssey 'Round the World, part of the larger Reading Greek Tragedy Online initiative, took place on Tuesday and Wednesday, December 8 and 9, 2020. Led by the Harvard University Center for Hellenic Studies, Odyssey 'Round the World was a 24hour event that featured performances of every rhapsody of the odyssey; note how the organizers wanted to avoid the word "book".

1 Another translation of the Iliad and the Odyssey, by the rock musician and poet Branimir (Johnny) Štulić, should also be taken into account, even though it was published in Serbia and currently has only a limited circulation: Homerus, Branimir Štulić, Božanska Ilijada, Beograd: Komuna, 1995; Homerus, Branimir Štulić, Božanska Odiseja, Beograd: Plato, 2010. 
The performances were recorded by students, faculty, and actors around the world. The collaboration was coordinated - each team was assigned a number of verses from the odyssey, they had to record the performances and send them to the coordinator - but, other than that, no rules or instructions were given, except for a gentle suggestion that the contributors connect Homer with their own culture. The contributors were encouraged to perform in their own language, but they could also use the original, or any other language (we used not only croatian, but a bit of Latin translation of Homer as well; part of the odyssey was performed in the American Sign Language). The odyssey could have been read, recited, sung, acted - and so it was.

The collaboration included a number of American universities, but also people from universities and other institutions in eighteen more countries - in Mexico, Peru, Canada, Argentina, Brasil; in Australia (Sydney); in Mozambique, Malawi, and South Africa; in China (Shanghai) and Turkey (Istanbul); in Cyprus, Greece, United Kingdom, Spain (Madrid), Hungary (Budapest), Italy (Bologna), and Croatia. All these performances can still be found and seen on the YouTube.

Before I invite you to think about the initiative, a few words about our contribution. The Croatian team had to prepare the book, or rhapsody, 23, the next to last in the Odyssey; the team included students and teachers from the University of Zagreb. We had enough ideas - as you will see if you check out our video, the ideas included even a puppet theatre with inverted roles of Odyssey and Penelope - but the main obstacles were technical; the sound and the images are not always ideal, and not in the least consistent from performer to performer. Anyway, this home-made quality fits well into the main idea of the project.

But, actually, what was the main idea of Odyssey 'Round the World? The organizers have not told us much, but the project offers some stimulating matter for thought. 
First, in my opinion, someone very happily noticed the coincidence that the Odyssey is divided in 24 books, just as there are 24 hours in the day. Join space to time and you get a whole day in which there has been a book of the odyssey recited - or, perhaps, transmitted - every hour by a different group, from a different part of the world.

Second, the project could be seen to reflect the original rhapsodic quality of the Homeric poems, known to Greeks from competitions such as the one in which Plato's Ion won the first prize. The similarity is there even though the scholars do not agree on exactly how the rhapsodes went about sewing or stitching together the parts of the Homeric poems - we are not even sure whether the entire Illiad and Odyssey were performed at the Panathenaic games - and even though what we did in 2020 was certainly not a competition, it was more of a collaboration (even though, of course, everybody tried to do their best).

Third, Odyssey 'Round the World - as it exists now on the YouTube channel - was hardly meant to be watched in its entirety at once. It is meant to be sampled. We click now on this video, now on that, skip forward, look at something again. The rhapsody was also not meant to be understood in its entirety, at least not directly. On the contrary, Odyssey 'Round the World gives us a chance to savour both languages we know and the ones we do not know, and to try and guess and recognize bits and pieces of Homer we know in all the incomprehensibility of a foreign language. It is all Homer, all that variety: parts we watch and parts we skip, parts we understand, and parts where we only guess what could something mean.

Finally, Odyssey 'Round the world reminds us of the oral, and aural, quality of Homer. In the antiquity people listened to his poetry, and recited it or read it aloud to audiences, much more than they read it silently. Homer was much more a performance than 
words on the page. Of course, the ancient oral performances happened in a live, face to face context, while ours were recorded in advance and distributed through YouTube. Contary to Greek rhapsodes, we do not know and we have not seen our audience. In that sense, the odyssey 'Round the World, however oral and performative, is very much of our time.

\section{** Conclusion}

To conclude. The collaboration with Odyssey 'Round the World, a project which presented Homer very much alive in a merry variety, made me strongly aware how limited Homer remained in the last 140 years of croatian culture. In Croatia, to a very large extent, Homer has been replaced by Tomo Maretić, and Maretić is growing more and more remote, becoming more and more of a museum exhibit. But Homer does not have to be a museum exhibit. We could look at him in other ways, with other priorities. We could - as Joel Christensen wrote of the Iliad and the Odyssey in another context - see something "like 24 hours of polyphonic music, played by musicians in separate rooms who can't really hear each other but are somehow working in concert. If we relax and let the composition fall over us, we can get some idea of the whole. But when we listen closely, we can get lost in the depth of each passing strain." Such Homer is chaotic - but it is also alive. Can we get a Homer that sounds alive in Croatian? I do not know. But Odyssey 'Round the World suggests we could, and should try - and it suggests that the way to achieve this lies somewhere outside of the box of national high culture. 